\title{
Review \\ PERSPECTIVES ON BIODIVERSITY SCIENCE IN BRAZIL
}

\author{
Fabio Rubio Scarano \\ UFRJ/CCS/IB - Depto. de Ecologia, C.P. 68020 - 21941-970 - Rio de Janeiro, RJ - Brasil. e-mail \\ $<$ fscarano@biologia.ufrj.br>
}

\begin{abstract}
Biodiversity issues in Brazil have reached a critical point. On one hand, biodiversity science is increasing in quality and quantity, however on the other, habitat destruction in all major biomes still maintain alarmingly high rates. This paradox, from a scientific perspective, has two central tenets that scientists should focus on. First, although science related to biodiversity is of high standard in Brazil as compared to that of peers in the world, it is still not at the leading edge of research. Second, the wealth of information built up by strong research programmes, such as Biota/Fapesp - to which this special issue of Scientia Agricola is dedicated - is beginning to help decision-makers to improve precision and quality of their decisions concerning the environment, but still much is left to be done in this respect. Therefore, I discuss some of the biodiversity issues that remain controversial and demand fast scientific growth. Tackling them Brazil may finally reach the leading edge of biodiversity research. Finally, I discuss how communication between scientists and decision-makers and the general public may be improved, highlighting how a strong education project is urgently needed from kindergarten to graduate programmes in order to solve the two problems above mentioned and definitely crack the paradox biodiversity knowledge vs. biodiversity destruction.
\end{abstract}

Key words: biodiversity-ecosystem function, global change, leading-edge science, scientific communication, scientific education

\section{PERSPECTIVAS DAS CIÊNCIAS DABIODIVERSIDADE NO BRASIL}

\begin{abstract}
RESUMO: A temática da biodiversidade no Brasil alcançou um ponto crítico onde, por um lado, a ciência da biodiversidade aumenta em quantidade e em qualidade, enquanto que por outro, a destruição de habitats nos grandes biomas brasileiros se mantém em taxas alarmantes. Eu defendo que este paradoxo, numa perspectiva científica, tenha dois princípios centrais nos quais cientistas talvez devessem se concentrar. Primeiramente, embora as ciências relacionadas à biodiversidade no Brasil sejam de alto padrão se comparadas com o que é produzido no resto do mundo, o país ainda não detém a ponta do conhecimento em nenhuma destas ciências. E segundo lugar, a riqueza de informações produzida por fortes programas de pesquisa - como o Biota/Fapesp, ao qual este número especial de Scientia Agricola é dedicado - está apenas começando a auxiliar tomadores-de-decisão a aumentar a precisão e a qualidade das decisões referentes ao meio ambiente, mas ainda há muito a ser feito a este respeito. Portanto, eu discuto alguns dos tópicos acerca da biodiversidade que permanecem controvertidos e demandam rápido crescimento científico. Eu proponho que atacando estes temas o Brasil talvez possa vir a alcançar a ponta do conhecimento em médio prazo. Em seguida, discuto como podem ser aprimoradas as vias de comunicação entre cientistas e tomadores-de-decisão e o público em geral, enfatizando como um forte programa educacional - que cubra do jardim de infância à pósgraduação - será imprescindível para solucionar os dois problemas acima e definitivamente romper com o paradoxo conhecimento da biodiversidade vs. destruição da biodiversidade.

Palavras-chave: biodiversidade-funcionamento de ecossistemas, mudanças globais, liderança científica, comunicação científica, educação científica.
\end{abstract}

\section{INTRODUCTION}

Science carried out in Brazil has reached unprecedented levels of productivity and international visibility. This country ranks among the top 20 as regards scientific productivity (number of contributions in ISIindexed journal; King, 2004) and is currently the $23^{\text {rd }}$ in number of paper citations (Essential Science Indicators, 2007). This is clearly a result of a strong policy of personnel training at the graduate level and of increasing investments in basic and applied science and technology (e.g., Holmgren \& Schnitzer, 2004; Roitman 2005; Glänzel et al., 2006; Leta et al., 2006). Federal government agencies such as CAPES (Brazil- 
ian Council for Graduate Studies), CNPq (Brazilian Council for Science and Technology) and FINEP (Funding Agency for Studies and Projects) play a major role in this process and, for at least the last couple of decades, state agencies such as Fapesp (Funding Agency for Scientific Research of São Paulo State) have decisively joined this initiative.

Fortunately, biodiversity science in Brazil followed this trend and had a major rise in recent years. Scarano \& Oliveira (2005), using ISI's Essential Science Indicators database, pointed out that the top ten fields of science in Brazil include "Ecology and Environment", "Plant and Animal Sciences" and "Agricultural Sciences”, disciplines which directly deal with biodiversity issues. Each of these disciplines then ranked among the top 20-21 in the world, when compared to other countries. The measure of this notable performance is that recent scientometric studies describe the Brazilian pattern of scientific production as "bio-environmental” (Glänzel et al., 2006; Leta et al., 2006). Although this performance in sciences related to biodiversity is undoubtedly a reason for great satisfaction, it is still not at the leading edge of research in any of them. The first objective of this report is to discuss necessary steps in order to reach such a status.

Scarano \& Oliveira (2005) also indicated an apparent paradox: while on one side biodiversity science in Brazil is clearly improving in quality and quantity, on the other side environmental degradation is reaching alarmingly high rates throughout the country. Amazon rain forest (Fearnside, 2005), cerrado (Cavalcanti \& Joly, 2002; Durigan et al., 2007) caatinga (Barbosa et al., 2005) and, perhaps most obviously, the Atlantic rain forest (Myers et al., 2000) - to name but a few - are all highly threatened biomes, with deep problems regarding biodiversity conservation and land use, still to be tackled both by scientists and decisionmakers. A similar paradox has been described by Melo et al. (2006): while Brazilian limnology is experiencing unprecedented growth, there are growing problems related to water quantity and quality in the country. The second objective of this report is to discuss how the gap between scientists and decision-makers in Brazil can be overcome as regards biodiversity issues.

\section{LEADING-EDGE BIODIVERSITY RESEARCH: IS IT CARRIED OUT IN BRAZIL?}

\section{From reproduction to innovation}

Professor Paulo Freire, perhaps the most outstanding name in Brazilian Education, has often argued that the average education practice in Brazil essentially fosters copy and reproduction of pre-existing models. Thus, autonomy and creative thinking are skills not necessarily trained in Brazilian students throughout
pre-University years (e.g. Freire, 1996/2004). The concerns of UNESCO with scientific education in Latin America and particularly in Brazil (see Werthein \& Cunha, 2005) are most likely consequence of the symptom diagnosed by Freire. As a result, higher education and even graduate training possibly suffer from a similar problem.

Recent reports have proposed that Brazilian research focusing on ecology and biodiversity conservation mostly consists of case studies and/or natural history descriptions (Barbosa et al., 2004; Scarano, 2006a). Despite the obvious relevance of such type of studies, and particularly considering that Ecology is typically a case-study science (Shrader-Frechette \& Mc Coy, 1993), the bulk of ecological and biodiversity theory ought to be more often tested. Ecological theory is fraught with problems (e.g. Peters, 1991), which is due to the young age of this science and also to the high level of complexity it deals with (ShraderFrechette \& Mc Coy, 1993; Scarano, 2006a). However, this has been no obstacle for the extensive use of such theoretical framework in applied actions, for instance, in biodiversity conservation. If on one hand it is positive that this science can turn theory into practice, on the other, from a Brazilian perspective, two main worries can be pointed out: most such theoretical background has not been built up in Brazilian biomes or equivalent; and Brazilian scientists do not often test such theories and predictions in Brazilian biomes. I have recently discussed how theory can be turned into dogma (Scarano, 2006a) and I proposed that it often does when it refers to conservation priority. If Brazil is considered one of the few countries in the world with a megadiversity of species, it is its duty to test such theories and to increase the knowledge of mankind regarding biodiversity issues.

Testing theories and challenging the established knowledge on biodiversity issues will bring Brazil to the forefront in sciences related to biodiversity. In present times, one can even argue that for Brazil to be at the leading-edge of biodiversity science is even a matter of national sovereignty (e.g. Mattos \& Scarano, 2002; Scarano, 2006a). It is important to highlight that this is by no means implying that Brazilians should "reinvent the wheel". In science, one must often reproduce in order to learn - however, creativity, innovation and critical reading must be stimulated and trained throughout the learning process, as proposed by Freire (1996/2004). Descriptive natural history studies and a strong taxonomic background, for instance, will continue to be highly important - however, they must be seen as a necessary structural layer upon which new theories and ideas will be built. 


\section{Species: the basic unit of hot research topics}

Perhaps one of the first concepts that comes to mind when one thinks about biodiversity is the concept of species. As with many other biological entities, the concept of species is by no means uncontroversial (see Levin, 1979; Luckow, 1995; Mallet, 1995; Lowe et al., 2004). Nevertheless, it is probably the most operational unit when it comes to dealing with questions regarding ecology or biodiversity.

At its frontier, biodiversity-related science frequently asks the following questions: how will species respond to a global change in scenario? from an ecosystem-function viewpoint, does a species identity matter? if a given species goes extinct, how does this affect other species at the local level? These three questions indicate that species as a unit or "currency" of biodiversity shall be central to understand issues at the global, ecosystem or community levels. However, at present there is hardly any general answer to these questions. This shows that ecology and environmental sciences have at this stage a very low predictive power (Sterelny \& Griffiths, 1999).

This low predictive power is an open avenue for Brazilian researchers interested in biodiversity to experiment on the leading-edge of science. Next I discuss, focusing on the three posed questions, some research lines that might prove rewarding to increase our predictive power as regards biodiversity issues.

Species and global change - Holt (1990) provided what is in my opinion the best prediction available for global change impacts upon species. He argued that any given species will change its abundance and/or distribution; or go extinct; or adapt and evolve. Although this may sound imprecise, Holt said, at that moment in time, that there were hardly any species to which we knew enough relevant ecology, physiology and genetics in order to allow good predictions about responses to climate change. Seventeen years later his statement still holds, despite recent progress in the gathering of empirical data and in tools for modeling future scenarios (for recent developments, see Buckeridge, 2007, who discusses such predictions for Brazilian vegetation types). However, despite all limitations of ecological and physiological research in producing such forecasts (as it will be discussed next), genetics is the discipline in which perhaps less is known at this stage. Very little is known of the possible genetic responses of species to climate change (Hadly et al., 2004). This knowledge should be essential to predict whether and which species should adapt or evolve, which is one of the three possible outcomes proposed by Holt for species faced by climate change.
Thus, an increased predictive capacity of the responses of a species to global change will need further developments in disciplines such as ecology, physiology and genetics, and will be essential for biodiversity conservation as for agricultural practices (e.g., Cerri et al., 2007).

Species and ecosystem function - Does the species identity - i.e., whether a given species is either species "a", "b" or "c" - matter for ecosystem functioning? There are many evidences indicating that indeed it does (Kareiva \& Levin, 2003; Scarano \& Dias, 2004; Scarano, 2006a) but that perhaps the detection of such species effect is dependent on spatial and temporal scales. The concept of functional types - i.e., groups of species that perform similar ecological functions within a given ecosystem (Wilson, 1999) - is central to this debate (Lavorel et al., 2007). Functional type classifications are essential tools to reduce complexity, since many species can supposedly be placed in a single "ecological pigeon-hole". Theoretically, an ecosystem with a high functional redundancy (where many species play a similar relevant ecological function; i.e. a given relevant functional type comprises a high diversity of species) is more stable than one with a low functional redundancy (Scarano \& Dias, 2004). The classification of plants in pioneer, secondary and climax - regarding their successional status - is probably the most common application of the concept among Brazilian authors, however many other approaches exist that are less commonly used in this country (e.g., Pillar \& Sosinski, 2003; Scarano, 2006b).

\section{Species extinction impact on other species}

- Based on the functional type rationale, it is to be expected that the local extinction of a functionally redundant species should do less harm to other species than the local extinction of a functionally singular species. My research group has proposed that for most of the marginal habitats of the Atlantic rain forest (i.e., restingas, swamps, inselbergs, high altitude vegetation), structure and function of the vegetation rely on singular or a few keystone species (Scarano 2002, 2006b; Dias et al., 2006; Medina et al., 2006; Dias \& Scarano, 2007). Thus, local extinction of such species should prove to be particularly harmful for other species at the local level. However, Simberloff (2003) examined the keystone species concept and offered a very balanced view about the impact of the extinction of individual species in communities and ecosystems. He argued that there is a major gap in measurements and empirical data, and that there is also a lack of quantification or explicit definitions of ecosystem "impact" and "importance". 


\section{What to measure and how?}

If the reader agrees that the three topics summarized above are essential to the progress of biodiversity science, the next question then would be how to design studies that address such issues. Field and laboratory experiments that manipulate species and environmental conditions, along with thorough quantitative analyses, shall be indispensable tools.

Laboratory experiments are essential to assess single species responses to possible consequences of global change, such as atmospheric $\mathrm{CO}_{2}$ enrichment (for a Brazilian example, within the Biota-Fapesp project, Aidar et al., 2002). However, while such studies provide good accounts of physiological comportment and contribute to forecasts, they may be less instructive when it comes to predicting ecological outcomes. Thus, field studies that experimentally manipulate atmospheric $\mathrm{CO}_{2}$, soil nutrients, water and other variables likely to be affected by global change are commendable. This is particularly necessary when the targets are communities or ecosystems rather than species individually.

Perhaps one of the most successful examples of field experiment on global change effects on biodiversity is that set in the Cedar Creek Long Term Ecological Research (LTER) site, in Minnesota, US. This experiment uses a free-air $\mathrm{CO}_{2}$ enrichment system (FACE; see Lewin et al., 1994) to produce an elevated $\mathrm{CO}_{2}$ concentration in the atmosphere of planted plots. The results obtained for these artificial plant communities are compared with control plots at ambient $\mathrm{CO}_{2}$ concentration. Reich et al. (2001; 2004), Ellsworth et al. (2004), and Dijkstra et al. (2005) are interesting examples of the achievements of this experiment. Nevertheless, even such high-cost field experiments are not free of criticism. The Cedar Creek LTER experiments are based on synthetically assembled plant communities, i.e. the experimental design determines species composition. It has often been argued that natural communities and ecosystems are likely to differ from artificial systems in their response to changes in diversity (e.g., Díaz et al., 2003). Alternatively, Díaz and co-authors argue that species removal experiments in naturally assembled communities can be more useful for ecological theory and also for applications in land-use and conservation. Their argument finds echo in the book edited by Kareiva \& Levin (2003) that comprises several chapters describing successful removal experiment studies for various different types of organisms.

However, removal experiments in natural communities also have some serious constraints related, for instance, to the difficulties in obtaining good and numerous replicates, and in controlling multiple variables.
Research permits for this type of study may not be easy to obtain either, particularly in conservation units. There are also some technical criticisms, particularly when such experiments are performed in a short timescale. Bonanomi et al. (2005) have recently made a simulation study by an individual-based competition model that produced evidence that the effects at population level were timescale-dependent, which shows the limitation of short-term species removal experiments, often used in competition studies.

Irrespective of the debate around the strength of the above methodologies in determining biodiversity and species relations to global change, ecosystem function and to other coexisting species, fact is that none of such tools are being significantly used or tested in Brazil. Perhaps, it is time that our major research programmes, such as Biota/Fapesp, focus on the caveats of some of these methodologies to simultaneously improve them and enhance our knowledge on biodiversity.

While Brazilian science is still short of field experiments aiming to solve biodiversity issues, some up-to-date quantitative tools are being tested in our ecosystems, while others are being developed and gaining international recognition. The structural equation modeling (SEM) was recently used to unveil mechanisms behind the facilitation effect that Clusia hilariana Schltdl. (Clusiaceae), a restinga tree, exerts on other plant species in situ (Dias \& Scarano, 2007). SEM is a development of "path analysis" that advanced mostly under the scope of social sciences and whose application is still much limited in ecology (e.g., Kubota et al., 2004; Taylor \& Irwin, 2004; Weiher et al., 2004). Fine examples of quantitative tools developed in Brazil for biodiversity studies under the scope discussed here are those produced by Pillar \& Sosinski (2003) and Rangel et al. (2006). The former represents a major advancement in functional type classification methodology, since it is a multivariate analysis that allows the use of binary, qualitative or quantitative data, or a mixture of different types of data. Moreover, it accounts for phenotypic plasticity, a relevant trait often overlooked by the functional-type theoretical domain. The latter produced the "Spatial Analysis in Macroecology", a package for spatial analysis in macroecology and biogeography. It includes in a single freeware package, a set of statistical tools that allows users to deal with the problem of spatial autocorrelation in biodiversity data. Last but not least, complex system theory and related analytical tools, recently revised by Souza \& Buckeridge (2004), also open a new and exciting avenue for biodiversity research. 
Finally, the examples discussed in this topic both demonstrate the creativity of some Brazilian researchers and the room that still exists for improvement in quantitative analytical tools related to biodiversity issues. It also shows that biodiversity science produced in Brazil could invest more time and effort into large-scale field experimentation. At this point, the next inevitable question is if Brazil finally reaches the status of a country that produces leading-edge biodiversity science, can the resulting knowledge improve environmental decisionmaking?

\section{SCIENCE SUBSIDISING DECISION-MAKING: CAN THIS GAP BE BRIDGED?}

There is no doubt that the development of science and of a worldwide "scientific culture" has been the main responsible for environmental policies in a global scale. The interesting and optimistic study of Hironoka (2003) shows that the number of countries with National Parks, or with a Ministry for Science and Technology, or with a Ministry for Environment (or equivalent) has had an astounding increase in the past few decades and keeps increasing. However, it is also true to say that decision-making as regards environmental issues is still poor, and not only in developing countries.

But why is this so? Two hypotheses seem to be concurrent in this respect: although theoretically sound, science on biodiversity produced is still not readily applicable to problem-solving; and/or the communication of science to decision-makers and the general public is poor. Next the first hypothesis is discussed from a global perspective, since it refers to science as a whole, and the second hypothesis from a national perspective, since it refers to a problem that needs urgently to be overcome in Brazil.

\section{Applicability of biodiversity science in solving biodiversity problems}

This report, while recognizing and exemplifying the important achievements of biodiversity science to date, has also shown some of the methodological and epistemological obstacles that are currently faced by scientists. However, there is another line of reflection and criticism related to a supposed lack of applicability on the solution of problems of some of the current scientific trends in biodiversity research.

Botkin et al. (2007) have made a strong criticism to current forecasts of the effects of global warming on biodiversity. They argue that projections of extinction rates are overestimates. Their critique is based on what they call a "Quaternary conundrum", i.e., while current empirical and theoretical ecological data predict that many species could be at risk from global warming, during the recent ice ages few extinctions are documented. They propose that this paradox is probably due to poor prediction of climate change impact on biodiversity, and present eight ways to improve forecasting. All eight steps are associated to methodological and epistemological obstacles to improve modeling. Their advice is that models should be improved so as to consider species persistence (in refugia, for instance) and multiple causes of biodiversity change. They add that greater use of fossil records and modern genetic tools (Hadly et al., 2004) should also improve forecasts. Undoubtedly, in order to propose better solutions to biodiversity-related problems, better forecasts will be essential.

Another case of heavy criticism on an ongoing trend of biodiversity science comes from Srivastava \& Vellend (2005). They argue that the current ecological paradigm of the relationship biodiversity-ecosystem function is unlikely to help conservation managers in practical decisions, although they admit that this theoretical domain might be useful for restoration practice. Again, as discussed above for the global warming-biodiversity theme, this critique is largely based on methodological and epistemological problems, particularly related to the fact that most biodiversity-ecosystem function research is confined to small spatial scales. These authors also consider that this type of research, in order to become applicable for conservation purposes, should expand to multitrophic systems, which are underrepresented. Lawler et al. (2003) are more optimistic, recognizing that biodiversity-ecosystem function experiments are mostly recent and few in number, but argue that in the long-term their results will help conservationists because this type of information is needed to protect and maintain viable communities.

The limitations of biodiversity science to solve biodiversity problems are also emphasized by an important Brazilian scientist and conservationist, Prof. Claudio Valladares-Pádua. In a recent paper in Conservation Biology, although acknowledging the relevance of production of knowledge on biodiversity, he argued that biological studies are often of reduced effect on restraining harmful natural-resource development and that effective solutions are generally related to economic changes and adoption of alternative land uses (Valladares-Pádua, 2006). Interestingly, this Special Issue brings two papers that discuss ecological consequences of land use changes (Silva et al., 2007a; 2007c). 


\section{Communication of science to decision-makers and the general public}

How can economy, land use and biodiversity be objectively dealt within a same package? Martins et al. (2006) have produced a Hybrid Human Development Index (Hybrid HDI, aka Environmental HDI, from the Portuguese "IDH Ambiental") that combines elements from the Human Development Index (HDI, which is known as the best international indicator for population quality of life) and the Environmental Sustainability Index (ESI, conceived at the Universities of Columbia and Yale, US). The motivation behind this study was that the authors found a low correlation between HDI and ESI. This means that many countries that are rich (high HDI) achieved such wealth at the expense of poor use of the environment (low ESI). The new index aims to correct this distortion and incorporates environmental variables (such as environmental pollution, available biodiversity, human vulnerability, socioinstitutional capacity, and global responsibility) into HDI (that accounts for parameters such as income, longevity and education). Thus, it reconciles human development with sustainability.

In a comparison among 139 countries, Brazil is currently $54^{\text {th }}$ in IDH, $11^{\text {th }}$ in ESI, and $39^{\text {th }}$ in the hybrid Environmental HDI. Martins et al. (2006) argue that the comparatively good performance of the country in aspects such as global responsibility, quality of water of soil (see Silva et al., 2007c, for a discussion about the relationship between soil loss and habitat quality), and available biodiversity, compensates for low income and educational problems and bring the country into a better ranking at the Environmental HDI.

These results lead to the following interpretations. First, many times in history, human development based on economic growth occurred at the expense of environmental resources. Second, from a sustainable human development viewpoint, Brazil is in a fragile situation where the remaining natural richness (which is comparatively very high) is under pressure due to social problems such as low income and poor education. The fragility of the second case is that it might have as outcome the first case itself (China is the most recent example of the first case type of growth; Martins et al., 2006; Valladares-Pádua, 2006). Therefore, in order to avoid an unsustainable human development model, Brazil will need to invest heavily on high quality education for all layers of society and achieve a better distribution of wealth.

This new index is a very promising tool produced by a Brazilian Master's student. This citation is also a strong support to Prof. Freire's claim that creativity and innovative spirit are essential steps of education, and that it can be achieved even at early stages of scientific training.
Education brings us back to the title of this topic. Communication of the high qualified science produced in the country to decision-makers and general public, which obviously includes school children of all ages, will be an indispensable step in order to achieve a high human development that is not at the expense of the quality of the environment or of the existence of other species. This is obviously easier to be said than to be done, but positive symptoms indicate that Brazil begins to make moves into this direction. At graduate level, the recent incentive to the socalled "Professional Masters" training, and the creation in 2006 of the first of such courses in Ecology and Conservation at "IPE-Instituto de Pesquisas Ecológicas” (Ecological Research Institute; www.ipe.org.br), creates the possibility for high-quality training of environmental agents and analysts working for IBAMA (the Brazilian Environmental Agency), for the Ministry of Environment, for governmental secretaries of environment and also for private companies and the third sector. Professionals who obtain such Masters degrees will not be leading scientists, but instead will be officials who can recognize, search and find good science and bring it to the realm of the entities where they work (Scarano \& Oliveira, 2005). At the school level, the Brazilian Ministry of Education has gathered some important researchers to examine school science textbooks, and as a result - for instance, in the field of ecology - many books have been removed from use due to inappropriate or wrong scientific content (Roque et al., 2007). Finally, many important research programs currently in activity in the country, such as Biota/Fapesp (Brandão \& Oliveira, 2002), the Brazilian LTER (Long Term Ecological Research Project; Bozelli et al., 2004), and LBA (Large Scale Biosphere-Atmosphere Experiment in Amazonia; Higuchi \& Higuchi, 2004) develop environmental education activities, based on scientific results of their own research. This practice is also followed by a number of conservation units, focusing on human populations in their vicinities (Pádua, 1995; Nagagata, 2006).

These numerous examples of activities concerning scientific education at various levels focusing on biodiversity and environmental aspects suggest that such initiatives are obviously not isolated cases, or strictly local in scope. However, academics, decisionmakers, private companies, educators and the third sector in Brazil should find a forum to share experiences and to prepare a structural background to optimize and expand such types of initiatives. The need of interinstitutional cooperation has been recently emphasized by Valladares-Pádua (2006) as an indispensable step towards better knowledge and use of Brazilian biodiversity. 


\section{FINAL REMARKS}

Science has two goals: to enhance human knowledge and to solve practical society problems. Scientists' skills in solving problems are related to the quality of the theories they produce (ShraderFrechette \& McCoy, 1993). This shows that the supposed dualism between "basic" and "applied" science is nonsensical. Biodiversity science, even in its purest form, is inclined to serve practical purposes at some stage. This overview shows that there are many problems, mainly of methodological and epistemological nature, with sciences related to biodiversity. Such problems often limit the extent to which these can produce practical solutions to environmental problems. However, the surprisingly numerous examples of success indicate that the application of biodiversity science to the solution of biodiversity problems is indeed a possibility (Shrader-Frechette \& McCoy, 1993; Barbosa et al., 2004). Our duty as scientists is to transform this from an eventual possibility into a routine action. This will demand both dedicated work on the frontiers of knowledge and concern with our communication skills, from the classroom to the media and back.

The vast amount of hard work that will be necessary to bring biodiversity science up to this status should not be discouraging. On the contrary, this challenge must be the very fuel to motivate young and old generations of scientists to pursue the leading-edge of biodiversity research. Along this process, Brazil may be brought both to the forefront of knowledge production and to a state where human development and social justice can be achieved in harmony with a healthy environment. In order to face this challenge, environmental education and a formal scientific education at all levels will be indispensable, and will be more effective whenever they stimulate creativity by practicing the abilities of discovery, invention and criticism (Bevilacqua, 2005).

\section{ACKNOWLEDGEMENTS}

To CNPq for a productivity grant, Faperj for a "Cientistas do Nosso Estado" grant, and CenpesPetrobras for funding the research which is the background for the discussion in this paper.

\section{REFERENCES}

AIDAR, M.P.M.; MARTINEZ, C.A.; COSTA, A.C.; COSTA, P.M.F.; DIETRICH, S.M.C.; BUCKERIDGE, M.S. Effect of atmospheric $\mathrm{CO}_{2}$ enrichment on the establishment of seedlings of jatobá, Hymenaea courbaril L. (Leguminosae-Caesalpinoideae). Biota Neotropica, v.2, n.1, 2002. Available at: http://www. biotaneotropica.org.br/v2 n1.
BARBOSA, F.A.R.; SCARANO, F.R.; SABARÁ M.G.; ESTEVES, F.A. Brazilian LTER: Ecosystem and biodiversity information in support of decision-making. Environmental Monitoring and Assessment, v.90, p.121-133, 2004.

BARBOSA, M.R.V.; CASTRO, R.; ARAÚJO, F.S.; RODAL, M.J.N. Estratégias para conservação da biodiversidade e prioridades para a pesquisa científica no bioma caatinga. In: ARAÚJO, F.S.; RODAL, M.J.N.; BARBOSA, M.R.V. (Ed.). Análise das variações da biodiversidade do bioma caatinga. Brasília: Ministério do Meio Ambiente, 2005, p.415-429.

BEVILACQUA, L. Ciência, um bem para o engrandecimento do espírito. In: WERTHEIN, J.; CUNHA, C. da (Ed.). Educação científica e desenvolvimento: o que pensam os cientistas. Brasília: UNESCO Brasil; Instituto Sangari, 2005. p.161-168.

BONANOMI, G.; GIANNINO, F.; MAZZOLENI, S. Negative plantsoil feedback and species coexistence. Oikos, v.111, p.311-321, 2005.

BOTKIN, D.B.; SAXE, H.; ARAÚJO, M.B.; BETTS, R.; BRADSHAW, R.H.W.; CEDHAGEN, T.; CHESSON, P.; DAWSON, T.P.; ETTERSON, J.R.; FAITH, D.P.; FERRIER, S.; GUISAN, A.; HANSEN, A.S.; HILBERT, D.W.; LOEHLE, C.; MARGULES, C.; NEW, M.; SOBEL, M.J.; STOCKWELL, D.R.B. Forecasting the effects of global warming on biodiversity. Bioscience, v.57, p.227-236, 2007.

BOZELLI, R.L.; FERREIRA, D.M.; ESTEVES, F.A.; ROCHA, A. de M.; LOPES, A.F. Educação ambiental: um processo embasado no conhecimento científico em longo prazo o determinante no cuidado com a natureza. In: ROCHA, C.F.D.; ESTEVES, F.A.; SCARANO, F.R. (Ed.). Pesquisas de longa duração na Restinga de Jurubatiba: ecologia, história natural e conservação. São Carlos: Rima, 2004. p.361-374.

BRANDÃO, C.R.; de OLIVEIRA, H.T. A terceira margem do Rio: a experiência de traduzir textos científicos sobre biodiversidade como material de educação ambiental de vocação biodiversa. Biota Neotropica, v.2, n.2, 2002. Available at: http:// www.biotaneotropica.org.br/v2 n2.

BUCKERIDGE, M.S. (Ed.). A biologia e as mudanças climáticas no Brasil, in press, 2007.

CAVALCANTI, R.B.; JOLY, C.A. Biodiversity and conservation priorities in the cerrado region. In: OLIVEIRA, P.S.; MARQUIS, R.J. (Ed.). The Cerrados of Brazil. New York: Columbia University Press, 2002. p.351-367.

CERRI, C.E.P.; SPAROVEK, G.; BERNOUX, M.; EASTERLING, W.E.E.; MELILLO, J.M.; CERRI, C.C. Tropical agriculture and global warming: impacts and mitigation options. Scientia Agricola, v.64, p.83-99, 2007.

DIAS, A.T.C.; SCARANO, F.R. Clusia as nurse plant. In: LÜTTGE, U. (Ed.). Clusia - a woody neotropical genus with remarkable plasticity and diversity. Heidelberg: Springer, 2007. p.55-72.

DIAS, A.T.C.; MATTOS, E.A. de; VIEIRA, S.A.; AZEREDO, J.V.; SCARANO, F.R. Aboveground biomass stock of native woodland on a Brazilian sandy coastal plain: estimates based on the dominant tree species. Forest Ecology and Management, v.226, p.364-367, 2006.

DÍAZ, S.; SYMSTAD, A.J.; CHAPIN III, F.S.; WARDLE, D.A.; HUENNEKE, L.F. Functional diversity revealed by removal experiments. Trends in Ecology and Evolution, v.18, p.140146, 2003.

DIJKSTRA, F.A; HOBBIE, S.E.; REICH, P.B.; KNOPS, J.M.H. Divergent effects of elevated $\mathrm{CO}_{2}, \mathrm{~N}$ fertilization, and plant diversity on soil $\mathrm{C}$ and $\mathrm{N}$ dynamics in a grassland field experiment. Plant and Soil, v.272, p.41-52, 2005.

DURIGAN, G.; SIQUEIRA, M.F. de; FRANCO, G.A.D.C. Threats to the cerrado remnants of the State of São Paulo, Brazil. Scientia Agricola, v.64, p.355-363, 2007.

ELLSWORTH, D.S.; REICH, P.B.; NAUMBURG, E.S.; KOCH, G.W.; KUBISKE, M.E.; SMITH, S.D. Photosynthesis, carboxylation and leaf nitrogen responses of 16 species to elevated $\mathrm{pCO}_{2}$, across four free air $\mathrm{CO}_{2}$ enrichment experiments in forest, grassland and desert. Global Change Biology, v.10, p.2121-2138, 2004. 
ESSENTIAL SCIENCE INDICATORS. Thomson ISI. Available at: http://portal.isiknowledge.com/portal.cgi?DestApp=ESI\&Func $=$ Frame. Access at: March 6 ${ }^{\text {th }}, 2007$.

FEARNSIDE, P. Deforestation in Brazilian Amazônia: history, rates and consequences. Conservation Biology, v.19, p.680-688, 2005.

FREIRE, P. Pedagogia da autonomia. São Paulo: Editora Paz e Terra, 1996/2004.

GLÄNZEL, W.; LETA, J.; THIJS, B. Science in Brazil. Part 1: a macro-level comparative study. Scientometrics, v.67, p.6786, 2006.

HADLY, E.A.; RAMAKRISHNAN, U.; CHAN, Y.L.; van TUINEN, M.; O’KEEFE, K.; SPAETH, P.A.; CONROY, C.J. Genetic response to climatic change: insights from ancient DNA and phylochronology. Public Library of Science - Biology, v.2, p.1600-1609, 2004. Available at: http://biology. plosjournals.org.

HIGUCHI, M.I.G.; HIGUCHI, N. A floresta amazônica e suas múltiplas dimensões: uma proposta de educação ambiental. Manaus: INPA, 2004.

HIRONAKA, A. Science and the environment. In: DRORI, G.S.; MEYER, J.W.; RAMIREZ, F.O.; SCHOFER, E. (Ed.). Science in the modern world polity: institutionalization and globalization. Stanford: Stanford University Press, 2003. p.249-264.

HOLMGREN, M.; SCHNITZER, S.A. Science on the rise in developing countries. Public Library of Science - Biology, v.2, p.10-13, 2004. Available at: http://biology.plosjournals.org.

HOLT, R.D. The microevolutionary consequences of climate change. Trends in Ecology and Evolution, v.5, p.311-315, 1990.

KAREIVA, P.; LEVIN, A.S. (Ed.). The importance of species: perspectives on expendability and triage. Princeton: Princeton University Press, 2003.

KING, D.A. The scientific impact of nations. Nature, v.430, p.311316, 2004.

KUBOTA, Y.; MURATA, H.; KIKUZAWA, K. Effects of topographic heterogeneity on tree species richness and stand dynamics in a subtropical forest in Okinawa Island, southern Japan. Journal of Ecology, v.92, p.230-240, 2004.

LAVOREL, S.; DÍAZ, S.; CORNELISSEN, J.H.C.; GARNIER, E.; HARRISON, S.P.; McINTYRE, S.; PAUSAS, J.G.; PÉREZHARGUINDEGUY, N.; ROUMET, C.; URCELAY, C. Plant functional types: are we getting any closer to the Holy Grail? In: CANADELL, J.G.; PATAKI, D.E.; PITELKA, L.F. (Ed.). Terrestrial ecosystems in a changing world. Heidelberg: Springer, 2007. p.149-164.

LAWLER, S.P.; ARMESTO, J.J.; KAREIVA, P. How relevant to conservation are studies linking biodiversity and ecosystem functioning? In: KAREIVA, P.; LEVIN, A.S. (Ed.). The importance of species: perspectives on expendability and triage. Princeton: Princeton University Press, 2003. p.294313.

LETA, J.; GLÄNZEL, W.; THIJS, B. Science in Brazil. Part 2: sectoral and institutional research profiles. Scientometrics, v.67, p.87-105, 2006.

LEVIN, D.A. The nature of plant species. Science, v.204, p.381384, 1979.

LEWIN, K.F.; HENDREY, G.R.; NAGY, J.; LaMORTE, R. Design and application of a free-air carbon dioxide enrichment facility. Agricultural and Forest Meteorology, v.70, p.15-29, 1994.

LOWE, A.; HARRIS, S.; ASHTON, P. Ecological genetics. Oxford: Blackwell, 2004.

LUCKOW, M. Species concept: assumptions, methods, and applications. Systematic Botany, v.20, p.589-605, 1995.

MALLET, J. A species definition for the Modern Synthesis. Trends in Ecology and Evolution, v.10, p.294-299, 1995.

MARTINS, A.R.P.; FERRAZ, F.T.; da COSTA, M.M. Sustentabilidade ambiental como nova dimensão do Índice de Desenvolvimento Humano dos países. Revista do BNDES, v.13, p.139-162, 2006.
MATTOS, E.A. de; SCARANO, F.R. Carbon sequestration: what really matters? - A reply to Buckeridge \& Aidar. Biota Neotropica, v.2, n.2, 2002. Available at: http:// www.biotaneotropica.org.br/v2 n2.

MEDINA, B.M.O.; RIBEIRO, K.T.; SCARANO, F.R. Plant-plant and plant-topography interactions on a rock outcrop at high altitude in southeastern Brazil. Biotropica, v.38, p.27-34, 2006.

MELO, A.S.; BINI, L.M.; CARVALHO, P. Brazilian articles in international journals on Limnology. Scientometrics, v.67, p.187-199, 2006.

MYERS, N.; MITTERMEIER, R.A.; MITTERMEIER, C.G.; FONSECA, G.A.B.; KENT, J. Biodiversity hotspots for conservation priorities. Nature, v.403, p.853-858, 2000.

NAGAGATA, E. A importância da educação ambiental como ferramenta adicional a programas de conservação. In: ROCHA, C.F.D.; BERGALLO, H.G.; ALVES, M.A.S.; VAN SLUYS, M. (Ed.). Biologia da conservação: Essências. São Carlos: Rima, 2006. p.563-583.

PÁDUA, S. Environmental education programmes for natural areas in underdeveloped countries - a case study in the Brazilian Atlantic Forest. In: PALMER, J.A. (Ed.). Planning education to care for the planet. Gland: IUCN, 1995. p.51-56.

PETERS, R.H. A critique for ecology. Cambridge: Cambridge University Press, 1991.

PILLAR, V.D.; SOSINSKI JR., E.E. An improved method for searching plant functional types by numerical analysis. Journal of Vegetation Science, v.14, p.323-332, 2003.

RANGEL, T.F.L.V.B.; DINIZ-FILHO, J.A.F.; BINI, L.M. Towards an integrated computational tool for spatial analysis in macroecology and biogeography. Global Ecology and Biogeography, v.15, p.321-327, 2006.

REICH, P.; KNOPS, J.; TILMAN, D.; CRAINE, J.; ELLSWORTH, D.S.; TJOELKER, M.; LEE, T.; WEDIN, D.; NAEEM, S.; BAHAUDDIN, D.; HENDREY, G.; JOSE, S.; WRAGE, K.; GOTH, J.; BENGSTON, W. Plant diversity enhances ecosystem responses to elevated $\mathrm{CO}_{2}$ and nitrogen deposition. Nature, v.410, p.809-812, 2001.

REICH, P.; TILMAN, D.; NAEEM, S.; ELLSWORTH, D.S.; KNOPS, J.; CRAINE, J.; WEDIN, D.; TROST, J. Species and functional group diversity independently influence biomass accumulation and its response to $\mathrm{CO}_{2}$ and $\mathrm{N}$. Proceedings of the National Academy of Sciences of the USA, v.101, p.10101-10106, 2004.

ROITMAN, I. Ciência para os jovens: falar menos e fazer mais. In: WERTHEIN, J.; CUNHA, C. da (Ed.). Educação científica e desenvolvimento: o que pensam os cientistas. Brasília: UNESCO Brasil; Instituto Sangari, 2005. p.119-127.

ROQUE, N.; EL-HANI, C.N.; VANZELA, A.L.L.; SOUZA, A.F.L.; MARQUES, A.C.; VIANA, B.F.; KAWASAKI, C.S.; LEME, C.L.D.; FARIA, D.; MEYER, D.; OMENA, E.; OLIVEIRA, E.S.; ASSIS, J.G. de A.; FREGONEZE, J.; QUEIROZ, L.P.; CARVALHO, L.M. de; NAPOLI, M.; CARDOSO, M.Z.; SILVEIRA, N. de A.; HORTA, P.A.; SANO, P.T.; ZUCOLOTO, R.B.; TIDON, R.; SILVA, S.A.H. da; ROSA, V.L. da; ROCHA, P.L.B. Brazilian high school biology textbooks: main conceptual problems in ecology and physiology. In: IOSTE INTERNATIONAL MEETING ON CRITICAL ANALYSES SCHOOL SCIENCE TEXTBOOKS, Tunis, 2007. Proceedings. Tunis: University of Tunis, 2007. p.908-916.

SCARANO, F.R. Structure, function and floristic relationships of plant communities in stressful habitats marginal to the Brazilian Atlantic rainforest. Annals of Botany, v.90, p.517-524, 2002.

SCARANO, F.R. Prioridades para conservação: a linha tênue que separa teorias e dogmas. In: ROCHA, C.F.D.; BERGALLO, H.G.; ALVES, M.A.S.; VAN SLUYS, M. (Ed.). Biologia da conservação: Essências. São Carlos: Rima, 2006a. p.23-39.

SCARANO, F.R. Plant community structure and function in a swamp Forest within the Atlantic rain Forest complex: a synthesis. Rodriguésia, v.57, p.491-502, $2006 \mathrm{~b}$. 
SCARANO, F.R.; DIAS, A.T.C. A importância de espécies no funcionamento de comunidades e ecossistemas. In: COELHO, A.S.; LOYOLA, R.D.; SOUZA, M.B.G. (Ed.). Ecologia teórica: desafios para o aperfeiçoamento da Ecologia no Brasil. Belo Horizonte: O Lutador, 2004. p.43-60.

SCARANO, F.R.; OLIVEIRA, P.E.A.M. Sobre a importância da criação de mestrados profissionais na área de Ecologia e Meio Ambiente. Revista Brasileira de Pós-Graduação, v.4, p.9096, 2005.

SHRADER-FRECHETTE, K.S.; McCOY, E.D. Method in ecology: strategies for conservation. Cambridge: Cambridge University Press, 1993.

SILVA, A.M. da; NALON, M.A.; KRONKA, F.J. do N.; ALVAREZ, C.A.; CAMARGO, P.B. de; MARTINELLI, L.A. Historical landcover/use in different slope and riparian buffer zones in watersheds of the State of São Paulo, Brazil. Scientia Agricola, v.64, p.325-335, 2007a.

SILVA, A.M. da; CASATTI, L.; ALVAREZ, C.A.; LEITE, A.M.; MARTINELLI, L.A.; DURRANT, S.F. Soil loss risk and habitat quality in streams of a meso-scale river basin. Scientia Agricola, v.64, p.336-343, 2007b.

SILVA, D.M.L. da; OMETTO, J.P.H.B.; LOBO, G. de A.; LIMA, W.P.; SCARANELLO, M.A.; MAZZI, E.; ROCHA, H.R. da. Can land use changes alter carbon, nitrogen and major ion transport in subtropical Brazilian streams? Scientia Agricola, v.64, p.317-324, 2007c.

SIMBERLOFF, D. Community and ecosystem impacts of singlespecies extinction. In: KAREIVA, P.; LEVIN, S.A. (Ed.). The importance of species: perspectives on expendability and triage. Princeton: Princeton University Press, 2003. p.221233.
SOUZA, G.M.; BUCKERIDGE, M.S. Sistemas complexos: novas formas de ver a Botânica. Revista Brasileira de Botânica, v.27, p.407-419, 2004.

SRIVASTAVA, D.S.; VELLEND, M. Biodiversity-ecosystem function research: is it relevant to conservation? Annual Review of Ecology, Evolution and Systematics, v.36, p.267294, 2005.

STERELNY, K.; GRIFFITHS, P.E. Sex and death: an introduction to philosophy of biology. Chicago: The University of Chicago Press, 1999.

TAYLOR, B.W.; IRWIN, R.E. Linking economic activities to the distribution of exotic plants. Proceedings of the National Academy of Sciences of the USA, v.101, p.17725-17730, 2004.

VALLADARES-PÁDUA, C. Importance of knowledge-intensive economic development to conservation of biodiversity in developing countries. Conservation Biology, v.20, p.700-701, 2006.

WEIHER, E.; FORBES, S.; SCHAUWECKER, T.; GRACE, J.B. Multivariate control of plant species richness and community biomass in blackland prairie. Oikos, v.106, p.151-157, 2004.

WERTHEIN, J.; CUNHA, C. da (Ed.). Educação científica e desenvolvimento: o que pensam os cientistas. Brasília: UNESCO Brasil; Instituto Sangari, 2005.

WILSON, J.B. Guilds, functional types and ecological groups. Oikos, v.86, p.507-522, 1999.

Received February 28, 2007

Accepted May 09, 2007 